\title{
The Influence of Different Ripening Stages, Harvest and Drying Methods on Quality of Unsulfured Sun-Dried Apricots
}

\author{
Emrah Çoban ${ }^{1, a}$, Hüseyin Karlıdağ ${ }^{2, b, *}$, İbrahim Kutalmış Kutsal ${ }^{2, c}$ \\ ${ }^{I}$ Department of Horticulture, Institute of Graduate Studies, Malatya Turgut Özal University, 44210 Malatya, Turkey \\ ${ }^{2}$ Department of Horticulture, Faculty of Agriculture, Malatya Turgut Özal University, 44210 Malatya, Turkey
}

${ }^{*}$ Corresponding author

\section{A R T I C L E I N F O A B S T R A C T}

Research Article

This study was carried out between 2017 and 2018 to determine physical and chemical influences of two drying methods (drying on wooden fruit drying trays and drying cloths), two harvesting periods (commercial / physiological maturity and late harvest), and two harvesting methods (harvesting by hand and shaking) on dried fruit samples of Hacıhaliloğlu and Kabaaşı cultivars. Titrable acidity, browning level, total phenolic content, antioxidant activity (ABTS), color $\left(L^{*}, \mathrm{a}^{*}\right.$, $\left.\mathrm{b}^{*}\right), \mathrm{pH}$, humidity and water activity (aw) parameters of dried fruit samples were examined. Results indicated that different harvesting periods, methods and drying methods significantly affected almost all fruit quality parameters. $L$ value was higher in apricots dried on trays than dried on the cloths. $L^{*}$ values of dried apricots ranged from 27,13 to 54,74 . Similarly, moisture content and water activity values were also found to be lower in apricots dried on wooden fruit drying trays than dried on clothes. When chemical parameters were examined, it was observed that phenolic compounds and total antioxidant contents decreased with fruit ripening. The effect of the applications on drying efficiency was not determined as significant, on the contrary, the individual weights of the dried apricots harvested at the late period were found significantly higher and the number of dried apricots per kilogram was lower. As a result of the study, it was concluded that in sun-dried apricot production, harvesting at late period and the drying on trays positively affected various quality parameters.

\section{Keywords:}

Dried apricot

Sun drying

Antioxidant

Phenolic content

\section{Introduction}

According to the FAO statistical database, the world production of apricots was 4,111,076 tonnes in 2018 . Turkey is the leading producer of approximately $20 \%$ of the world's apricots $(811,609 \mathrm{t})$ and provides about $75 \%$ of the world's dried apricots (FAO, 2020). Despite widespread production in several regions of the world, it has been stated that the optimal climatic and geographical conditions in eastern Turkey's Malatya region allow the production of apricots well-known and appreciated by consumers for their characteristics such as high dry matter, sugar content, and aroma (Munzuroglu et al., 2003; Akin et al., 2008). More than 50\% of the fresh apricots and 90 $95 \%$ of the country's dried apricots are produced in this area (TUIK, 2020). Hacıhaliloğlu, Çataloğlu, Kabaaşı, Soğanc1, Çöloğlu, Hasanbey, and Zerdali (wild forms) are the most frequently cultivated apricot cultivars in Malatya (Asma, 2000). Although other cultivars are also important, in Malatya, approximately $90-95 \%$ of apricot orchards were established with Hacıhaliloğlu and Kabaaşı varieties (Anonymous, 2014)
Drying of fruits which are applicable to many species is a common method for preserving juicy fruits / fresh fruits open-air sun drying method that gives the opportunity of considerable savings since the source of energy is free, is practiced widely in hot climates and tropical countries.

The aim of drying apricots is to reduce the content of moisture to a level that allows for long-term safe storage. In Turkey, open-air sun drying is the most common drying method for apricots, requiring low capital, simple equipment and low energy input (El Halouatand Labuza, 1987). Nonetheless, this approach has a variety of drawbacks also has many advantages. The most critical of these problems during the drying process is the undesired darkening of the dried apricots.

Today, there are two different harvesting methods used in Malatya; picking the fruits by hand and shaking branches by hand or shaker machine. Besides, two different methods are commonly used for drying the harvested apricots: drying on wooden fruit drying trays and on drying cloths. Although these methods have traditionally been 
used for many years, their effects on the quality properties of dried apricots have not been reported in the literature. On the other hand, the appropriate harvest time for sundried apricot production is still controversial.

Therefore, in the current study, we aimed to determine some physical and chemical changes in Hacihaliloğlu and Kabaaşı apricot varieties harvested in different ripening periods, dried on trays and cloths after harvesting with different methods; by hand and shaking.

\section{Materials and Methods}

\section{Materials}

This research was carried out during the years of 2017 and 2018 in an apricot orchard located in Battalgazi district of Malatya province. The study material consisted of Kabaaşı and Hacıhaliloğlu apricot cultivars were 20 years old orchard and samples collected from these varieties were used.

\section{Harvesting Time}

The study included two different harvest times. The first of these was the commercial / physiological maturity level (Güneyli and Onursal, 2014), determined according to the Brix values which were 22 and 19 for Hacihaliloğlu and Kabaaşı, respectively. The second was the late harvest represented by the Brix values were 24 and 22 for Hacıhaliloğlu and Kabaaşı, respectively, and this was approximately one week after the first harvest period in both years.

\section{Harvesting Methods}

The study consisted of two different harvesting methods. In harvesting by hand method, fruits at the same maturity level were picked by hand from the tree. In shaking, the harvest was carried out by handshaking at the intensity which would allow the fruits of the same maturity level to be shed without damaging the branches of the tree. Before the process, tarps were placed under the branches to reduce the damage and contamination of the fruits.

\section{Drying Methods}

The fruits harvested via both methods were brought to the drying area and spread on two different materials (cloth and wooden trays) and left for drying under direct sun. The cloth was made of white and $0.5 \mathrm{~mm}$ thick cloth, and wooden trays $(0.5 \times 1 \mathrm{~m}$ scales $)$ were light wooden colored and made by leaving a $0.5 \mathrm{~cm}$ space between the rods at the bottom to allow vantilating from the underside. Fruits were laid on both materials in a single row and not overlapping each other.

\section{Number of Dried Apricots per Kilogram}

One kilogram of fruit was weighed from each application and the weighed fruits were counted individually.

\section{Dry Yield}

The drying yield was calculated according to the following formula; (Asma, 1996)

$$
\text { Dry Yield }(\%)=\frac{\text { Weight of Dried Apricots }(\mathrm{kg})}{\text { Weight of Fresh Apricots }(\mathrm{kg})} \times 100
$$

\section{Color Properties}

The color values $\left(L^{*}, \mathrm{a}^{*}\right.$ and $\left.\mathrm{b}^{*}\right)$ of the dried apricots were determined using a Reflectance Chroma Meter CR 210 (Minolta Co. Ltd., Osaka, Japan). The instrument was calibrated before each measurement with a white ceramic tile.

\section{pH and Titrable Acidity}

The $\mathrm{pH}$ value was determined potentiometrically with a $\mathrm{pH}$ meter according to the method proposed by Cemeroğlu (2010). For this purpose, approximately $10 \mathrm{~g}$ of homogeneous dried apricot mass was weighed and allowed to rehydrate in $90 \mathrm{~mL}$ of distilled water for 1 day at $4^{\circ} \mathrm{C}$. This mixture was then homogenized in a high-speed blender for 3 minutes and then filtered through coarse filter paper. $\mathrm{pH}$ measurements were made in this filtrate. The same filtrate was also used for titration acidity determinations. For this purpose, $25 \mathrm{ml}$ of filtrate was taken and titrated with an adjusted $\mathrm{NaOH}$ solution to $\mathrm{pH}$ 8.1. The titration acidity was calculated as $\mathrm{g} / 100 \mathrm{ml}$ of anhydrous malic acid on dry weight basis.

\section{Moisture Content}

The moisture content ( $\%$ dry basis) of the dried samples was determined using an air oven set at $105^{\circ} \mathrm{C}$. All samples were divided into five portions and dried following a standard method (Feldsine et al., 2002). The moisture content of the samples was calculated on a percent dry basis, and the average value of the five samples was used.

\section{Water Activity}

The water activity values of the samples were determined using a water activity measuring device (Thermoconstanter Novasina TH 200, Zurich, Switzerland). Measurements were made at $25^{\circ} \mathrm{C}$.

\section{Browning}

Browning was measured in duplicate according to the method developed for dried carrots by Baloch et al. (1973) with minor revision in sample preparation described by Özkan and Cemeroğlu (2002). The extraction of the watersoluble brown pigment was carried out with $20 \mathrm{~mL} \mathrm{~L}^{-1}$ acetic acid containing $10 \mathrm{~mL} \mathrm{~L}^{-1}$ formaldehyde. Interfering carotenoid pigments were removed with lead acetate and ethyl alcohol. Formaldehyde was used to remove the interfering $\mathrm{SO}_{2}$. Absorbance of supernatants were recorded at 420 and $600 \mathrm{~nm}$, using a UV-VIS double-beam spectrophotometer (Shimadzu UV-1800; Shimadzu Corp., Kyoto, Japan). The browning was calculated by subtracting absorbance at $600 \mathrm{~nm}$ (for turbidity) from those of $420 \mathrm{~nm}$. The results were expressed as "absorbance at $420 \mathrm{~nm} \mathrm{~g}^{-1}$ sample dried weight."

\section{Total Phenolic Contents and Antioxidants Activity} Assays

Total phenolic content was determined using the FolinCiocalteu method (Spanos and Wrolstad, 1992). The extract was transferred to $1 \mathrm{ml}$ of Erlenmeyer and mixed with $46 \mathrm{ml}$ of distilled water and $1 \mathrm{ml}$ of Folin-Ciocalteau solution. After the mixture was left to stand for 3 minutes, $3 \mathrm{ml}$ of $2 \%$ sodium carbonate solution was added and stirred for 120 minutes on a magnetic stirrer. At the end of this period, absorbance against the vertex at $760 \mathrm{~nm}$ wavelength was measured on the spectrophotometer. Gallic acid is used as a standard. Results are given as gallic acid equivalent ( $\mu \mathrm{g} \mathrm{GAE} / \mathrm{mg}$ sample). 
The fruit extract's radical scavenging activity against DPPH (Fluka, Steinheim, Germany) was carried out with slight modifications, based on the procedures of BrandWilliam, Cuvelier, and Berset (2005). Fruit extract aliquots $(100 \mathrm{~mL})$ were mixed with $1.9 \mathrm{~mL}$ of a DPPH methanol solution $(1 \mathrm{mg} / \mathrm{mL})$ and the absorbance was measured after $60 \mathrm{~min}$ at $520 \mathrm{~nm}$. A calibration curve by calculating the absorbance of established Trolox concentrations was collected. The findings were presented in the form of mmol Trolox per $100 \mathrm{~g} \mathrm{DM}$.

\section{Statistical Analysis}

Obtained data were subjected to statistical analyses performed using SPSS 23.0 for Windows software. Results were evaluated according to Duncan's test $(\mathrm{P} \leq 0.05)$.

\section{Results and Discussion}

\section{Number of Dried Apricots per Kilogram}

The physical parameters measured in dried fruits of Hacıhaliloğlu and Kabaaşı cultivars are given in Table 1 and Table 2. In terms of number of dried apricots per kilogram, significant differences were observed in both cultivars, years, and the harvest time. In Hacıhaliloğlu cultivar, the maximum number of dried fruits was obtained from the apricots harvested in normal harvest time by hand and dried on trays (162) while the minimum number was obtained from the ones which harvested late by hand and dried on cloths (138), in 2017. Similar results were found in 2018 (Table 1.). In Kabaaşı cultivar, this value varied between 118 and 146. Similar to Hacihaliloğlu, the maximum number of dried fruits were obtained from the apricots harvested in normal harvest time by hand and dried on trays (118) while the minimum value was obtained from harvested late by hand and dried on cloths (146). Similar results were obtained in 2018 for Kabaaşı variety. In this parameter, no statistical differences were observed between the years. According to the stated data, it was determined that late harvest significantly decreased the number of fruits per kilogram in both years and cultivars. Apricot has three different development periods, first fast, then slow and last again fast (Karlıdağ, 1998). It was determined that a very important part of the weight increase in fruits occurred in the third growth period (Karaçalı, 2014; Karlıdağ, 1998) and it was also determined that the increase in weight continued slightly after this period (Karlıdağ, 1998). In this study, the number of fruits in one kilogram of apricots harvested in the late period was found lower than the ones harvested in the normal period, probably due to the increase in the amount of dry matter (TSS). Thus, in studies conducted with related apricot varieties, it was determined that the amount of TSS increased in apricot fruits with the increase in late ripening (Bolat and Karlıdağ, 1999; Karlıdağ and Bolat, 2007).

\section{Dry Yield}

The results of dry yield values are presented in Table 1 and Table 2 which were varied between 25.3-30.1\% and $25.9 \%-29.5 \%$ in Hacıhaliloğlu and Kabaaşı, respectively. The lowest dry yield value was obtained from the fruits of the Hacıhaliloğlu apricot cultivar harvested in the normal period by shaking and dried in trays with $25.3 \%$. The differences between the dry yield values in both cultivars were not found statistically significant in both years.

Table 1. Some physical parameters measured in dried fruits of Hacrhaliloğlu in 2017 and 2018

\begin{tabular}{|c|c|c|c|c|c|c|c|c|c|c|c|}
\hline \multirow{2}{*}{$\begin{array}{l}\text { Harvest } \\
\text { Methods }\end{array}$} & \multirow{2}{*}{$\begin{array}{c}\text { Drying } \\
\text { Materials }\end{array}$} & \multicolumn{2}{|c|}{ NDAK } & \multicolumn{2}{|c|}{ Drying Yield (\%) } & \multicolumn{2}{|c|}{$L^{*}$} & \multicolumn{2}{|c|}{$a^{*}$} & \multicolumn{2}{|c|}{$b^{*}$} \\
\hline & & 2017 & 2018 & 2017 & 2018 & 2017 & 2018 & 2017 & 2018 & 2017 & 2018 \\
\hline \multicolumn{12}{|c|}{ Harvest Time: Normal } \\
\hline \multirow{2}{*}{ By Hand } & loth & $156^{\mathrm{a}}$ & $160^{\mathrm{a}}$ & 29.0n.s & $27.6 n . s$ & $31.19^{\mathrm{ab}}$ & $29.20^{\mathrm{c}}$ & $11.50^{\mathrm{ab}}$ & $6.56^{\mathrm{b}}$ & $1.24 \mathrm{n} . \mathrm{s}$ & $10.66^{\mathrm{b}}$ \\
\hline & Tray & $162^{\mathrm{a}}$ & $162^{\mathrm{a}}$ & 26.9n.s & $26.7 n . s$ & $28.52^{\mathrm{b}}$ & $27.70 \mathrm{~d}$ & $11.44^{\mathrm{ab}}$ & $4.53^{c}$ & $0.26 \mathrm{n} . \mathrm{s}$ & $7.13^{c}$ \\
\hline \multirow{2}{*}{ Shaking } & Cloth & $160^{\mathrm{a}}$ & $160^{\mathrm{a}}$ & 28.7 n.s & $27.2 \mathrm{n} . \mathrm{s}$ & $30.20^{\mathrm{ab}}$ & $29.90^{\mathrm{bc}}$ & $10.28^{b}$ & $6.80^{\mathrm{b}}$ & $16.75 \mathrm{n} . \mathrm{s}$ & $11.53^{\mathrm{ab}}$ \\
\hline & Tray & $160^{\mathrm{a}}$ & $160^{\mathrm{a}}$ & 27.6n.s & $25.3 \mathrm{n} . \mathrm{s}$ & $33.39^{\mathrm{ab}}$ & $31.63^{\mathrm{ab}}$ & $11.09^{\mathrm{ab}}$ & $9.46^{\mathrm{a}}$ & 14.89n.s & $11.56^{\mathrm{ab}}$ \\
\hline \multicolumn{12}{|c|}{ Harvest Time: Late } \\
\hline \multirow{2}{*}{ By Hand } & Cloth & $138^{\mathrm{b}}$ & $140^{\mathrm{b}}$ & 30.1 n.s & $29.3 n . s$ & $34.46^{\mathrm{a}}$ & $31.93^{\mathrm{ab}}$ & $13.22^{\mathrm{a}}$ & $6.60^{\mathrm{b}}$ & 11.87 n.s & $9.63^{\mathrm{b}}$ \\
\hline & Tray & $142^{\mathrm{b}}$ & $142^{\mathrm{b}}$ & $29.8 n . s$ & $28.6 n . s$ & $29.50^{\mathrm{ab}}$ & $33.03^{\mathrm{a}}$ & $12.51^{\mathrm{ab}}$ & $9.80^{\mathrm{a}}$ & 14.95n.s & $13.26^{\mathrm{a}}$ \\
\hline \multirow{2}{*}{ Shaking } & Cloth & $140^{\mathrm{b}}$ & $137^{\mathrm{b}}$ & 29.6n.s & 29.7n.s & $28.47^{\mathrm{b}}$ & $30.70^{\mathrm{bc}}$ & $12.00^{\mathrm{ab}}$ & $6.56^{\mathrm{b}}$ & $14.55 \mathrm{n} . \mathrm{s}$ & $10.93^{\mathrm{ab}}$ \\
\hline & Tray & $144^{\mathrm{b}}$ & $142^{\mathrm{b}}$ & 28.9n.s & 28.9n.s & $29.31^{\mathrm{ab}}$ & $29.20^{c}$ & $12.23^{\mathrm{ab}}$ & $6.56^{\mathrm{b}}$ & 15.36n.s & $10.66^{\mathrm{b}}$ \\
\hline
\end{tabular}

NDAK: Number Of Dried Apricots Per Kilogram, The difference between the values indicated by different letters in the same column is important at the level of $\mathrm{P}<0.05$, Comparisons were performed separately for each year.

Table 2. Some physical parameters measured in dried fruits of Kabaaşı in 2017 and 2018

\begin{tabular}{|c|c|c|c|c|c|c|c|c|c|c|c|}
\hline \multirow{2}{*}{$\begin{array}{l}\text { Harvest } \\
\text { Methods }\end{array}$} & \multirow{2}{*}{$\begin{array}{c}\text { Drying } \\
\text { Materials }\end{array}$} & \multicolumn{2}{|c|}{ NDAK } & \multicolumn{2}{|c|}{ Drying Yield (\%) } & \multicolumn{2}{|c|}{$L^{*}$} & \multicolumn{2}{|c|}{$a^{*}$} & \multicolumn{2}{|c|}{$b^{*}$} \\
\hline & & 2017 & 2018 & 2017 & 2018 & 2017 & 2018 & 2017 & 2018 & 2017 & 2018 \\
\hline \multicolumn{12}{|c|}{ Harvest Time: Normal } \\
\hline \multirow{2}{*}{ By Hand } & 1 & $140^{\mathrm{a}}$ & $140^{\mathrm{a}}$ & 27.9n.s & $26.4 n . s$ & $34.74 n . s$ & $50.36^{\mathrm{ab}}$ & $12.17^{\mathrm{a}}$ & 5.13n.s & $1.13 \mathrm{n} . \mathrm{s}$ & $10.10^{\mathrm{ab}}$ \\
\hline & Tray & $146^{\mathrm{a}}$ & $142^{\mathrm{a}}$ & $26.2 \mathrm{n} . \mathrm{s}$ & 25.9 & $30.25 \mathrm{n} . \mathrm{s}$ & 59.5 & $11.93^{\mathrm{ab}}$ & $6.13 n . s$ & $5.55 \mathrm{n} . \mathrm{s}$ & $9.03^{b}$ \\
\hline \multirow{2}{*}{ Shaking } & Cloth & $142^{\mathrm{a}}$ & $140^{\mathrm{a}}$ & 26.7n.s & $26.8 \mathrm{n} . \mathrm{s}$ & $34.80 \mathrm{n} . \mathrm{s}$ & $47.80^{\mathrm{bc}}$ & $10.49^{a b}$ & $3.90 \mathrm{n} . \mathrm{s}$ & 24.37 n.s & $8.30^{\mathrm{b}}$ \\
\hline & Tray & $140^{\mathrm{a}}$ & $142^{\mathrm{a}}$ & 27.6n.s & 25.9n.s & $32.61 \mathrm{n} . \mathrm{s}$ & $50.30^{\mathrm{ab}}$ & $12.05^{\mathrm{ab}}$ & $4.56 \mathrm{n} . \mathrm{s}$ & $20.38 \mathrm{n} . \mathrm{s}$ & $7.90^{\mathrm{b}}$ \\
\hline \multicolumn{12}{|c|}{ Harvest Time: Late } \\
\hline \multirow{2}{*}{ By Hand } & Cloth & $118^{b}$ & $120^{\mathrm{b}}$ & 29.1 n.s & 28.9n.s & 28.50 n.s & $49.43^{\mathrm{abc}}$ & $12.35^{\mathrm{a}}$ & $5.50 \mathrm{n} . \mathrm{s}$ & 14.91n.s & $8.86^{\mathrm{b}}$ \\
\hline & Tray & $124^{\mathrm{b}}$ & $122^{\mathrm{b}}$ & $27.8 \mathrm{n} . \mathrm{s}$ & $26.7 \mathrm{n} . \mathrm{s}$ & $31.64 n . s$ & $50.76^{\mathrm{ab}}$ & $10.75^{\mathrm{ab}}$ & $6.03 \mathrm{n} . \mathrm{s}$ & $15.40 \mathrm{n} . \mathrm{s}$ & $12.36^{\mathrm{a}}$ \\
\hline \multirow{2}{*}{ Shaking } & Cloth & $120^{\mathrm{b}}$ & $120^{\mathrm{b}}$ & $29.5 \mathrm{n} . \mathrm{s}$ & $27.3 n . s$ & 28.71n.s & $52.00^{\mathrm{ab}}$ & $10.49^{\mathrm{ab}}$ & 5.16n.s & $21.52 \mathrm{n} . \mathrm{s}$ & $9.96^{\mathrm{ab}}$ \\
\hline & Tray & $122^{b}$ & $124^{\mathrm{b}}$ & 28.3n.s & $26.8 \mathrm{n} . \mathrm{s}$ & $29.83 \mathrm{n} . \mathrm{s}$ & $47.13^{c}$ & $9.78^{\mathrm{b}}$ & 5.13n.s & $19.45 \mathrm{n} . \mathrm{s}$ & $10.06^{\mathrm{ab}}$ \\
\hline
\end{tabular}

NDAK: Number Of Dried Apricots Per Kilogram, The difference between the values indicated by different letters in the same column is important at the level of $\mathrm{P}<0.05$, Comparisons were performed separately for each year. 


\section{Colour Properties}

In both experiment years, $L^{*}, a^{*}$ and $b^{*}$ values of the dried fruits of Hacıhaliloğlu and Kabaaşı apricot cultivars harvested at different periods and dried by different techniques are shown in Table 1 and Table 2. In 2017, the highest value of $\mathrm{L}$ was obtained from the fruits of Kabaaş1 which were harvested by shaking in the normal period and dried in the cloth (34.80) while the lowest was obtained from Hacıhaliloğlu fruits harvested by hand and dried in trays in the normal period (28.52). In the same year, the highest value for another fruit color value, $a^{*}$, was obtained from the Hacıhaliloğlu fruits which were harvested by hand at the late harvest period and dried in cloths (13.22). The lowest value of $a^{*}$ was obtained from the fruits of Kabaaş1, which were harvested by shaking in the late period and dried in trays (9.78). When the results of parameter $b^{*}$ are analyzed, it is seen that the highest value is obtained from the Kabaaşı fruits that were harvested by shaking in the normal period and dried in cloths (24.37). In this trial year, the lowest value of this parameter was obtained from Hacıhaliloğlu fruits harvested by hand and dried in kerevet (wooden platform used for drying) in the normal period (10.26).

The highest $\mathrm{L}$ value was measured in the peels of dried fruits in 2018 was obtained from Kabaaşı fruits, which were harvested by shaking in the normal period and dried in trays $(59.53)$. The lowest $L^{*}$ value was obtained from the fruits of Hacıhaliloğlu, which was harvested by shaking in the late period and dried in trays (29.20). In the same year, the highest value for another fruit color value, $a^{*}$, was obtained from the Hacihaliloğlu fruits, which was harvested by hand in the late period and dried in trays (9.80). The lowest a value was obtained from the fruits of Hacıhaliloğlu, which were harvested by hand and dried in trays in the normal period (4.53). When the $b^{*}$ values of 2018 are analyzed, it is seen that the highest value is obtained from the Hacihaliloğlu, which was harvested by hand and dried in trays in the late period (9.80). The lowest value for this parameter in this year was obtained in Hacıhaliloğlu fruits harvested by hand and dried in trays in the normal period (7.13).

According to the results of the statistical analysis, the differences between the $L^{*}$ values of the apricot fruits which were dried on cloths and trays after harvesting by hand and shaking at different periods were found significant. In a study conducted in Hacihaliloğlu cultivar, $L^{*}, a^{*}$ and $b^{*}$ values of unsulfured dried apricots were determined as 30.6, 10.7 and 11.3, respectively (Karabulut et al., 2007), and this results were in accordance with ours. Results indicated that harvesting method and drying material do not have a regular effect on the $L^{*}$ value, here under, it is understood that these two factors do not directly affect the $L^{*}$ value. However, regardless of the harvest period, hand-harvested apricots appear to have higher $L^{*}$ values than the apricots harvested by the shaking method. Hand-harvested apricot fruits are dried to be lighter than harvested by shaking. This is thought to be related to the injuries of the fruits falling to the ground during shaking. Also, considering that very dark dried apricot fruits are not preferred by consumers, it can be said that the result obtained is noteworthy.

\section{pH and Titrable Acidity}

The $\mathrm{pH}$ values of apricot varieties for 2017 and 2018 are given in Tables 3 and 4 . The $\mathrm{pH}$ values of dried apricot fruits varied between 5.58 and 6.00 in the Hacihaliloğlu variety in all applications in both years of the trial. In Kabaaş1 variety, these values varied between 5.57 and 5.90. The highest $\mathrm{pH}$ value was measured as 6.00 in Hacıhaliloğlu fruits harvested by shaking at normal period and dried on cloths. The lowest $\mathrm{pH}$ value was determined as 5.58 in Hacıhaliloğlu fruits harvested by shaking at late period and dried on trays. In both years and varieties, the effects of different harvest periods and different harvest methods and different drying materials on the $\mathrm{pH}$ content of the fruits were not found statistically significant.

The titration acidity values of Hacihaliloğlu fruits, which were dried in trays and cloths after harvesting by hand and shaking at different periods, varied between 0.58 and 0.86 respectively, and the same values for Kabaaş1 fruits varied between 0.38 and 0.85 , respectively. (Table 3 and Table 4). The highest titrable acidity value was measured as $0.86 \%$ in Hacıhaliloğlu fruits that were harvested by hand at normal period and dried on the cloth, and in the fruits harvested at normal period and dried in trays in Kabaaşı variety. The lowest value was determined as $0.38 \%$ in the fruits of Kabaaş1, which were harvested in the late period by shaking and dried in trays.

There are different types and amounts of organic acids in fruits and vegetables, depending on the species and variety. In fruits, the high sugar / acid ratio is sweet, and the low is an indicator that sour taste will predominate. According to the statistical analysis, the differences among the applications on the titration acidity values of dried apricot fruits were significant. When the charts are examined, it is seen that the titration acidity values are higher in the dried apricots harvested in the normal harvest period and the late harvesting period given lower aciditiy value in the apricots. The amount of sugar increases with maturity in fruits and the amount of dominant acid decreases (Asma and Ozturk 2005). It has been determined that the amount of dry matter (Brix) and sugars (reducing sugar, total sugar, and sucrose) enhance with maturity in apricots harvested at different maturity periods (Karlıdağ and Bolat, 2007).

\section{Moisture Content}

The moisture values of apricot varieties harvested at different periods with different methods and dried on trays and clothes for both years are given in Table 3 and Table 4. The moisture values of dried apricot fruits varied between $13,29 \%$ and $16,10 \%$ in Hacthaliloğlu cultivar in all applications in both years of the experiment. In Kabaaş1 variety, these values ranged between $13.50 \%$ and $15.41 \%$. The highest moisture value was measured as $16.10 \%$ in Hacıhaliloğlu fruits harvested by hand at late harvest period and dried on cloths. The lowest humidity value was determined as $13.29 \%$ in Hacıhaliloğlu fruits harvested by shaking at normal harvest period and dried on cloths. In both years and cultivars, the effects of different harvest periods and different harvest methods and different drying materials on the moisture content of dried fruits were found statistically significant. These differences were probably due to fruit maturity caused by harvest period, since the moisture content is higher in the fruits harvested at the late harvest period (Table 3 and Table 4). This may be due to 
increase in the amount of Brix in the fruit with ripening and the increase in the amount of water held in the fruit because the increase of the water-soluble substances in the fruit may cause the water potential in the fruit to decrease (increase in the osmotic potential) and therefore the amount of water lost by the diffusion from the fruit.

\section{Water Activity}

The water activity values varied between 0.41 and 0.65 in Hacıhaliloğlu, and between 0.40 and 0.61 in Kabaaş1 (Tables 3 and Table 4). The highest water activity value (0.61) was obtained in Hacıhaliloğlu fruits which were harvested by hand in late period and dried in trays. The lowest value was determined as 0.40 in which harvested by hand and dried on trays at the normal period in the Kabaaş1 variety.

In general, dried fruits have a water activity value of 0.60 to 0.75 , and dried vegetables are between 0.30 and 0.40 (Anonymous, 1992). The lower limit of water activity in which microorganisms that spoil food is assumed to be 0.90 for bacteria, 0.85 for yeasts and $0.70-0.75$ for molds (Cemeroğlu and Özkan 2009). When the water activity drops below 0.60, there is no microbiological activity. Almost all of the water activity values obtained from the study were below 0.60 . Values above 0.60 were obtained from apricots harvested in the late period. This situation can be explained by the decrease in the water potential due to the increase of the dry matter with ripening.

\section{Browning Level}

The browning levels of dried apricot fruits of Hacıhaliloğlu and Kabaaşı apricot varieties ranged between 0.39 and 0.49 . The highest browning value was measured as 0.48 in the fruits of Hacihaliloğlu, which was harvested by hand at normal period and dried on trays. The lowest browning value was obtained as 0.39 in Kabaaş1 fruits, which was harvested by shaking at normal period and dried on cloths. In both years and varieties, the effects of different harvest periods and different harvest methods drying materials on the browning level of dried apricots were found statistically significant.

Significant enzymatic and non-enzymatic changes and color browning are observed at the beginning of drying in apricot fruits. Maillard (non-enzymatic) browning reactions can occur during storage or before during drying (Cemeroğlu and Özkan 2009). During the drying and storage of fruits, in the first stage of Maillard reactions between reducing sugars and amines, the amino groups of amino acids are connected to the hydroxyl group of reducing sugars (glucose and fructose), forming $\mathrm{N}$ glucosamine. As a result of subsequent polycondensation events, brown-colored melanoidins are formed (Asmaand Öztürk, 2005). In this study, the browning level was found to be lower in the apricots dried in trays than in the cloths. This is thought to be related to the air permeability of the underside of the trays. However, this may have caused the apricots dried in the cloths to be more affected by the soil temperature.

Table 3. Some chemical parameters measured in dried fruits of Hacıhaliloğlu in 2017 and 2018

\begin{tabular}{|c|c|c|c|c|c|c|c|c|c|c|c|}
\hline \multirow{2}{*}{$\begin{array}{l}\text { Harvest } \\
\text { Methods }\end{array}$} & \multirow{2}{*}{$\begin{array}{c}\text { Drying } \\
\text { Materials }\end{array}$} & \multicolumn{2}{|c|}{$\mathrm{pH}$} & \multicolumn{2}{|c|}{$\begin{array}{c}\text { Titrable Acidity } \\
(\%)\end{array}$} & \multicolumn{2}{|c|}{$\begin{array}{c}\text { Moisture } \\
(\%)\end{array}$} & \multicolumn{2}{|c|}{$\begin{array}{c}\text { Water Activity } \\
(\mathrm{aW})\end{array}$} & \multicolumn{2}{|c|}{$\begin{array}{c}\text { Browning Values } \\
\text { (A420 g-1 DW) }\end{array}$} \\
\hline & & 2017 & 2018 & 2017 & 2018 & 2017 & 2018 & 2017 & 2018 & 2017 & 2018 \\
\hline \multicolumn{12}{|c|}{ Harvest Time: Normal } \\
\hline \multirow{2}{*}{ By Hand } & Cloth & 5.91n.s & 5.96n.s & $0.86^{\mathrm{a}}$ & $0.86^{\mathrm{a}}$ & $14.68^{\mathrm{c}}$ & $14.90^{\mathrm{b}}$ & $0.56^{\mathrm{b}}$ & $0.42^{\mathrm{de}}$ & $0.42^{\mathrm{cd}}$ & $0.48^{\mathrm{a}}$ \\
\hline & Tray & 5.75n.s & $5.94^{\mathrm{ab}}$ & $0.81^{\mathrm{b}}$ & $0.80^{\mathrm{b}}$ & $13.84^{\mathrm{d}}$ & $14.01^{\mathrm{c}}$ & $0.57^{\mathrm{b}}$ & $0.41^{\mathrm{e}}$ & $0.45^{\mathrm{abc}}$ & $0.41^{\mathrm{e}}$ \\
\hline \multirow{2}{*}{ Shaking } & Cloth & 5.78n.s & $6.00 \mathrm{n} . \mathrm{s}$ & $0.76^{\mathrm{c}}$ & $0.77^{\mathrm{c}}$ & $13.29^{\mathrm{e}}$ & $13.68^{\mathrm{c}}$ & $0.56^{\mathrm{b}}$ & $0.43^{\mathrm{cd}}$ & $0.47^{\mathrm{abc}}$ & $0.39^{f}$ \\
\hline & Tray & 5.73n.s & 5.95n.s & $0.75^{\mathrm{c}}$ & $0.75^{\mathrm{d}}$ & $14.13^{\mathrm{d}}$ & $14.04^{\mathrm{c}}$ & $0.59^{\mathrm{b}}$ & $0.42^{\mathrm{de}}$ & $0.49^{\mathrm{a}}$ & $0.46^{\mathrm{bc}}$ \\
\hline \multicolumn{12}{|c|}{ Harvest Time: Late } \\
\hline \multirow{2}{*}{ By Hand } & Cloth & 5.78n.s & 5.99n.s & $0.67^{\mathrm{d}}$ & $0.67^{\mathrm{e}}$ & $16.10^{\mathrm{a}}$ & $16.04^{\mathrm{a}}$ & $0.59^{\mathrm{b}}$ & $0.45^{\mathrm{b}}$ & $0.48^{\mathrm{ab}}$ & $0.39^{f}$ \\
\hline & Tray & $5.59 \mathrm{n} . \mathrm{s}$ & 5.97n.s & $0.64^{\mathrm{e}}$ & $0.65^{\mathrm{f}}$ & $14.53^{\mathrm{c}}$ & $14.52^{\mathrm{b}}$ & $0.65^{\mathrm{a}}$ & $0.44^{\mathrm{bc}}$ & $0.40^{\mathrm{d}}$ & $0.42^{\text {de }}$ \\
\hline \multirow{2}{*}{ Shaking } & Cloth & 5.66n.s & 5.82n.s & $0.58^{f}$ & $0.58^{\mathrm{g}}$ & $15.79^{\mathrm{a}}$ & $15.57^{\mathrm{a}}$ & $0.64^{\mathrm{a}}$ & $0.46^{\mathrm{a}}$ & $0.44^{\mathrm{a}-\mathrm{d}}$ & $0.44^{\mathrm{cd}}$ \\
\hline & Tray & $5.58 \mathrm{n} . \mathrm{s}$ & 5.96n.s & $0.67^{\mathrm{d}}$ & $0.65^{\mathrm{f}}$ & $15.42^{\mathrm{b}}$ & $14.90^{\mathrm{b}}$ & $0.58^{b}$ & $0.42^{\mathrm{de}}$ & $0.44^{\mathrm{a}-\mathrm{d}}$ & $0.46^{\mathrm{b}}$ \\
\hline
\end{tabular}

The difference between the values indicated by different letters in the same column is important at the level of $\mathrm{P}<0.05$.

Comparisons were performed separately for each year.

Table 4. Some chemical parameters measured in dried fruits of Kabaaşı in 2017 and 2018

\begin{tabular}{|c|c|c|c|c|c|c|c|c|c|c|c|}
\hline \multirow{2}{*}{$\begin{array}{l}\text { Harvest } \\
\text { Methods }\end{array}$} & \multirow{2}{*}{$\begin{array}{l}\text { Drying } \\
\text { Materials }\end{array}$} & \multicolumn{2}{|c|}{$\mathrm{pH}$} & \multicolumn{2}{|c|}{$\begin{array}{c}\text { Titrable Acidity } \\
(\%)\end{array}$} & \multicolumn{2}{|c|}{$\begin{array}{c}\text { Moisture } \\
(\%)\end{array}$} & \multicolumn{2}{|c|}{$\begin{array}{l}\text { Water Activity } \\
(\mathrm{aW})\end{array}$} & \multicolumn{2}{|c|}{$\begin{array}{l}\text { Browning Values } \\
\text { (A420 g-1 DW) }\end{array}$} \\
\hline & & 2017 & 2018 & 2017 & 2018 & 2017 & 2018 & 2017 & 2018 & 2017 & 2018 \\
\hline \multicolumn{12}{|c|}{ Harvest Time: Normal } \\
\hline \multirow{2}{*}{ By Hand } & Cloth & 5.64 n.s & $5.75 \mathrm{n} . \mathrm{s}$ & 0.81 n.s & $0.58^{\mathrm{c}}$ & $13.85^{\mathrm{d}}$ & $13.51^{\mathrm{c}}$ & $0.53^{\mathrm{c}}$ & $0.40^{\mathrm{d}}$ & $0.48^{\mathrm{a}}$ & $0.39^{\mathrm{de}}$ \\
\hline & Tray & $5.73 \mathrm{n} . \mathrm{s}$ & 5.71n.s & $0.85 \mathrm{n} . \mathrm{s}$ & $0.65^{\mathrm{b}}$ & $14.17^{\mathrm{c}}$ & $14.53^{\mathrm{b}}$ & $0.53^{\mathrm{c}}$ & $0.41^{\mathrm{c}}$ & $0.40^{\mathrm{d}}$ & $0.47^{\mathrm{a}}$ \\
\hline \multirow{2}{*}{ Shaking } & Cloth & 5.87n.s & 5.86n.s & $0.76 \mathrm{n} . \mathrm{s}$ & $0.57^{\mathrm{c}}$ & $13.50^{\mathrm{e}}$ & $13.54^{\mathrm{c}}$ & $0.55^{\mathrm{b}}$ & $0.41^{\mathrm{c}}$ & $0.48^{\mathrm{a}}$ & $0.38^{\mathrm{e}}$ \\
\hline & Tray & 5.70n.s & $5.82 \mathrm{n} . \mathrm{s}$ & $0.86 \mathrm{n} . \mathrm{s}$ & $0.74^{\mathrm{a}}$ & $14.13^{\mathrm{c}}$ & $14.45^{\mathrm{b}}$ & $0.55^{\mathrm{b}}$ & $0.40^{\mathrm{d}}$ & $0.47^{\mathrm{ab}}$ & $0.40^{\mathrm{cd}}$ \\
\hline \multicolumn{12}{|c|}{ Harvest Time: Late } \\
\hline \multirow{2}{*}{ By Hand } & Cloth & $5.62 \mathrm{n} . \mathrm{s}$ & 5.68n.s & $0.62 \mathrm{n} . \mathrm{s}$ & $0.56^{\mathrm{c}}$ & $14.50^{\mathrm{b}}$ & $14.61^{\mathrm{b}}$ & $0.55^{\mathrm{b}}$ & $0.43^{\mathrm{b}}$ & $0.40^{\mathrm{cd}}$ & $0.45^{\mathrm{ab}}$ \\
\hline & Tray & $5.74 \mathrm{n} . \mathrm{s}$ & 5.79n.s & $0.57 \mathrm{n} . \mathrm{s}$ & $0.51^{\mathrm{d}}$ & $15.33^{\mathrm{a}}$ & $15.41^{\mathrm{a}}$ & $0.55^{\mathrm{b}}$ & $0.44^{\mathrm{a}}$ & $0.48^{\mathrm{a}}$ & $0.41^{\mathrm{c}}$ \\
\hline \multirow{2}{*}{ Shaking } & Cloth & $5.68 \mathrm{n} . \mathrm{s}$ & 5.86n.s & $0.56 \mathrm{n} . \mathrm{s}$ & $0.57^{\mathrm{c}}$ & $14.29^{\mathrm{bc}}$ & $14.52^{\mathrm{b}}$ & $0.61^{\mathrm{a}}$ & $0.44^{\mathrm{a}}$ & $0.42^{\mathrm{cd}}$ & $0.40^{\mathrm{cd}}$ \\
\hline & Tray & $5.57 \mathrm{n} . \mathrm{s}$ & 5.90n.s & $0.38 \mathrm{n} . \mathrm{s}$ & $0.47^{\mathrm{e}}$ & $14.52^{\mathrm{b}}$ & $14.45^{\mathrm{b}}$ & $0.58^{\mathrm{ab}}$ & $0.41^{\mathrm{c}}$ & $0.44^{\mathrm{bc}}$ & $0.44^{\mathrm{b}}$ \\
\hline
\end{tabular}

The difference between the values indicated by different letters in the same column is important at the level of $\mathrm{P}<0.05$.

Comparisons were performed separately for each year. 


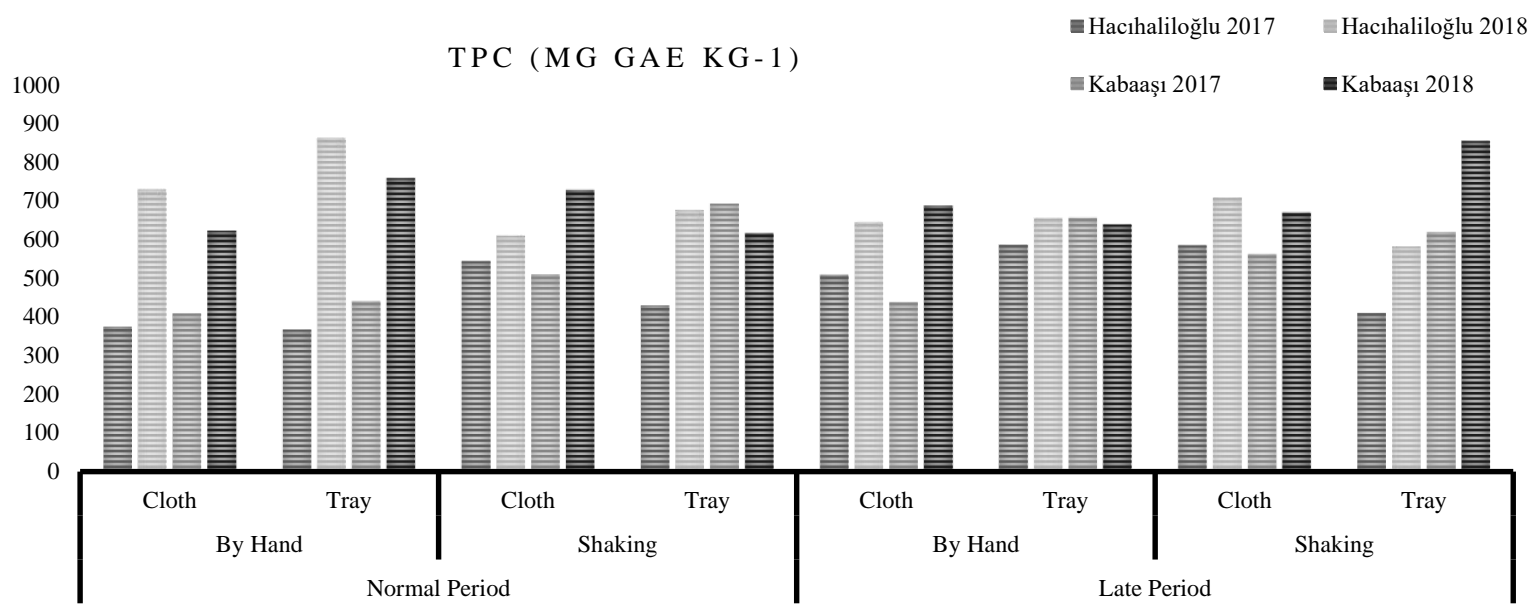

Figure 1. Total Phenolic Contents of dried fruits of Hacıhaliloğlu and Kabaaşı in 2017 and 2018

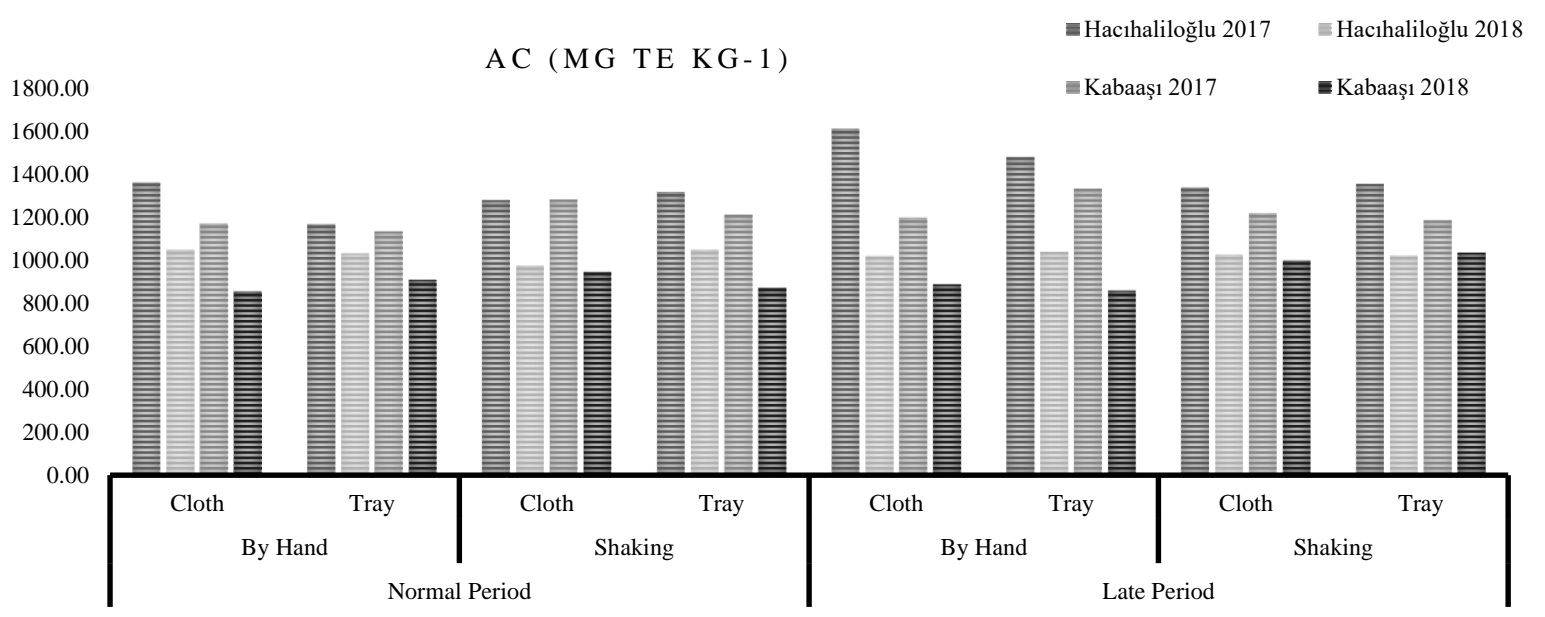

Figure 2. Antioxidant Capacities of dried fruits of Hacıhaliloğlu and Kabaaşı in 2017 and 2018

In a study by Keleş (1987), it was stated that the color of processed foods changed as a result of enzymatic and non-enzymatic browning reactions. In the same study, it was reported that an increase in browning levels was observed with the increase of temperature during heat treatment.

\section{Total Phenolic Content and Antioxidant Activity}

The total phenolic contents of the apricot varieties dried on trays and cloths after harvesting by hand and shaking in normal and late periods are given in Figure 1 and Figure 2. Total phenolic contents of dried apricots obtained from all applications in both years of the study ranged between $366.43 \mathrm{mg}$ GAE / $\mathrm{kg}$ and $862.02 \mathrm{mg}$ GAE / $\mathrm{kg}$ in Hacıhaliloğlu while the same value ranged between 408.90 $\mathrm{mg}$ GAE / kg and $853.96 \mathrm{mg}$ GAE / kg in Kabaaş1. The highest total phenolic content value was obtained from Hacihaliloğlu apricot fruits that were harvested by hand at normal period and dried on trays. The lowest value was $366.43 \mathrm{mg}$ GAE / $\mathrm{kg}$ in dried fruits of Hacihaliloğlu harvested by hand at normal period and dried on trays. According to the statistical analysis, the effects of different harvesting methods, periods and drying materials on total phenolic contents of Hacihaliloğlu and Kabaaşı apricot varieties were found significant. However, this effect was not stable among the applications and therefore no prominent application could be determined.
Phenolic substances are functional compounds that are present in almost every fruit in small or large amounts (Keleş, 1987; Cemeroğlu and Özkan, 2009). Apricot contains high levels of phenolic substances. In a study conducted by Bennetta et al. (2011) on various fruits, the total amount of phenolic substance of dried apricots was determined as $19.1 \mu \mathrm{mol} \mathrm{GAE} / \mathrm{g}$ dried fruit. In this study, the total phenolic contents of apricots dried on the trays are higher for both experiment years and varieties regardless of the harvest period and method.

Antioxidant activity values of apricots dried on trays and cloths after harvesting by hand and shaking at different harvest periods are shown in Figure 1 and Figure 2. When the specified graphs are examined, it can be concluded that the antioxidant activity values of Hacihaliloğlu apricot variety was found between $974.39 \mathrm{mg} \mathrm{TE} / \mathrm{kg} \mathrm{TA}$ and $1611.48 \mathrm{mg}$ TE/kg TA, while Kabaaşı apricot variety gave between $854.36 \mathrm{mg}$ TE/kg TA and $1334.25 \mathrm{mg}$ TE/kg TA. The lowest antioxidant activity value determined with $854.36 \mathrm{mg}$ TE/kg TA value, in which Hacıhaliloğlu fruits harvested by hand at the normal period and dried on the cloths, and the highest value was the Hacihaliloğlu fruits which were harvested by hand at the late period and dried on cloths, with the value of $1611.48 \mathrm{mg}$ TE $/ \mathrm{kg}$ TA. The differences between total antioxidant content values were statistically significant. However, as in the total amount of phenolic substances, there has not been any practice that comes to the fore. 
The antioxidant activity of fruits and vegetables occurs with the total effect of vitamins A, C, E, organic acids, flavonoids, anthocyanins, and carotenoids, primarily the amount of phenolic compounds (Mayer et al., 2000; Sivritepe 2000). Since the antioxidant content has become an important parameter in terms of the quality of fruits and vegetables; Evaluation of the changes in antioxidant contents after harvest has been a remarkable subject (Zavala et al., 2004). Antioxidant activity may be affected by factors such as climate, soil, stress conditions and storage conditions in foods that are stored for a long time (Kan, 2009). Antioxidant activity differences are observed even among the fruits in different canopy positions on the same tree (Karabulut et al., 2017).

It has been reported that cultivars grown in Malatya have higher antioxidant properties compared to other varieties (Güçlü et al., 2006). In this study, it was determined that the total antioxidant content was significantly affected by the harvest time, method and drying materials. When the related graphs are examined, it can be seen that the antioxidant activities of the apricots harvested at the late period were found to be lower than those harvested at normal period. Kulkarni and Aradhya (2005) reported that the antioxidant content of pomegranate fruits decreased by $13 \%$ during the ripening process, probably due to the decrease in the amount of phenolic substance and ascorbic acid in the same period.

\section{Conclusion}

Apricot, which is one of the most cultivated stone fruit species in the world, has a great importance and a strategic position especially for Turkey. In this context, studies to solve problems related to dried apricot are very important. According to the results, for the production of unsulfured dried apricots, it can be said that it is more appropriate to harvest the apricots later than those are sulfured since they are higher in dry matter and thus their individual weights are higher. Additionally, in terms of color measurements, in general, apricots dried on trays had lighter color than those dried on cloths. Although this parameter is significantly affected by the applications, it is concluded that these effects are not regular. It is thought that other factors such as temperature, light, physical properties of drying material also affect this parameter. Also, it has been demonstrated that hand harvest and shaking methods used in this study do not significantly affect the quality parameters of dried apricots. In this case, the shaking method, which is easier to apply, can be preferred instead of the hand harvest method. Finally, when total phenolic content and antioxidant activities are examined, seen that these parameters decrease in fruits with ripening. Especially recently, the importance of these substances, understood for human health, is a criterion desired by conscious consumers. However, apricots harvested during periods of high amounts of these substances will not be preferred much since they will have low eating quality when dried.

\section{Acknowledgements}

This study was supported by İnönü University Scientific Research Coordination Unit. Project Number: FYL-2018-1035

\section{References}

Abdelhaq EH, Labuza TP. 1987. Air Drying Characteristics of Apricots. Journal of Food Science. https://doi.org/10.1111/ j.1365-2621.1987.tb06608.x

Akin EB, Karabulut I, Topcu A. 2008. Some compositional properties of main Malatya apricot (Prunus armeniaca L.) varieties. Food Chemistry. https://doi.org/ 10.1016/ j.foodchem.2007.08.052

Anonymous 1992. Dried Apricot Standards of Turkish Statistical Institute. Ankara, Türkiye.

Anonymous, 2014. Apricot Workshop Report, website: https://www.tarimorman.gov.tr/BUGEM/Belgeler/Duyurula r/kayisimail.pdf

Asma BM, Akça Y. 1996. Hacıhaliloğlu Kayısı Çeşidinde Derim Zamanının Kuru Kayısı Kalitesi ve Randımanı Üzerine Etkisinin Saptanması Üzerine Bir Araştırma, YYÜ Ziraat Fak. Der, 6(1): 181-189.

Asma BM. 2000. Apricot Growing. Evin Publishing (in Turkish).

Asma BM, Ozturk K. 2005. Analysis of morphological, pomological and yield characteristics of some apricot germplasm in Turkey. Genetic Resources and Crop Evolution. https://doi.org/10.1007/s10722-003-1384-5.

Baloch AK, Buckle KA, Edwards RA. 1973. Measurement of non-enzymicbrowning of dehydratedcarrot. Journal of the Science of Food and Agriculture. https://doi.org/ 10.1002/jsfa.2740240406

Bennett LE, Jegasothy H, Konczak I, Frank D, Sudharmarajan S, Clingeleffer PR. 2011. Total polyphenolicsand anti-oxidant properties of selected dried fruits and relation ships to drying conditions. Journal of Functional Foods. https://doi.org/ 10.1016/j.jff.2011.03.005

Bolat I, Karlidağ H. 1999. The effects of harves tperiods on SO2 content and fruitquality of Turkish dried apricot. Acta Horticulturae.https://doi.org/10.17660/ActaHortic.1999.488. 99

Cemeroğlu B. 2010. General Methods in Food Analysis. Gida Teknolojisi Derneği Yayınları.

Cemeroğlu B, Özkan M. 2009. Fruit and Vegetable Processing Technology. Grup Publishing.

Cuvelier ME, Berset C. 2005. Phenolic compounds and plante xtracts protect paprika against UV-induceddiscoloration. International Journal of Food Scienceand Technology. https://doi.org/10.1111/j.1365-2621.2004.00909.x

FAO, 2020. Food and Agriculture Organization of the United Nations. FAOSTAT. Available from: http://www.fao.org/ faostat/en/\#data/QC [Accessed 22May 2020]

Feldsine P, Abeyta C, Andrews WH. 2002. AOAC International methods committee guidelines for validation of qualitative and quantitative food microbiological official methods of analysis. Journal of AOAC International. https://doi.org/ 10.1093/jaoac/85.5.1187

Güçlü K, Altun M, Özyürek M, Karademir SE, Apak R. 2006. Antioxidantcapacity of fresh, sun- andsulphited-dried Malatya apricot (Prunus armeniaca) assayedby CUPRAC, ABTS/TEAC andfolinmethods. International Journal of FoodScienceandTechnology. https://doi.org/10.1111/j.13652621.2006.01347.x

Güneyli A, Onursal CE, 2014. Ilıman İklim Meyvelerinde Hasat Kriterleri. Meyvecilik Araştırma Enstitüsü Müdürlüğü Yayınları (in Turkish)

Kan T. 2009. Kayısıda (Prunus armeniaca L.) Kükürtleme uygulamasının bazı antioksidant madde içerikleri üzerine etkileri. PhD Dissertation. Institute of Natural and Applied Sciences, Van Yuzuncu Yil University, Van, Turkey.

Karabulut I, Bilenler T, Sislioglu K, Gokbulut I, Seyhan F, Ozdemir IS, Ozturk B. 2018. Effect of fruit can opypositions on theproperties of apricot (Prunus armeniaca L.) varieties. Journal of FoodBiochemistry. https://doi.org/10.1111/ jfbc. 12458 
Karabulut I, Topcu A, Duran A, Turan S, Ozturk B, 2007. Effect of hot airdryingand sun drying on colorvalues and $\beta$-carotene content of apricot (Prunus armenica L.). LWT - Food Science and Technology. https://doi.org/10.1016/ j.lwt.2006.05.001

Karaçalı İ. 2014. Bahçe Ürünlerinin Muhafaza ve Pazarlanması, Ege Üniversitesi Ziraat Fakültesi Yayınları.

Karlıdă H. 1998. Hekimhan (Malatya)'da farklı rakımlarda yetiştirilen bazı kayısı çeşitlerinde meyvenin fiziksel ve kimyasal özelliklerindeki değişimin incelenmesi. Master Dissertation. Institute of Natural and Applied Sciences, Ataturk University, Erzurum, Turkey.

Karlıdağ H, Bolat İ. 2007. Farklı Rakımlarda Yetiştirilen Bazı Kayısı Çeşitlerinin Fiziksel ve Kimyasal Özelliklerindeki Değișimin İncelenmesi. Türkiye V. Ulusal Bahçe Bitkileri Kongresi, Erzurum, Turkey, 4-7 September 2007.

Keleş F. 1987. Gıdalarda Enzimatik Esmerleşme ve Kontrolü. Turkish Journal of Agriculture and Forestry11: 105-121.

Kulkarni AP, Aradhya SM, 2005. Chemical changes and antioxidant activity in pomegranatearils during fruit development. Food Chemistry. https://doi.org/10.1016/ j.foodchem.2004.09.029
Meyer AS, Suhr KI, Nielsen P, Holm F. 2002. Natural food preservatives. Minimal Processing Technologies in the Food Industries. https://doi.org/10.1533/9781855736795.124

Munzuroglu O, Karatas F, Geckil H. 2003. The vitamin and selenium contents of apricotfruit of different varieties cultivated in different geographical regions. Food Chemistry. https://doi.org/10.1016/S0308-8146(03)00064-5

Özkan M, Cemeroglu B, 2002. Desulphiting dried apricots byexposureto hot airflow. Journal of the Science of Food and Agriculture. https://doi.org/10.1002/jsfa.1266

Sivritepe N. 2000. Asma, üzüm ve şaraptaki Antioksidantlar. Gıda Dünya Publisihing.

Spanos GA, Wrolstad RE. 1992. Phenolics of Apple, Pear, and White Grape Juices and Their Changes with Processing and Storage. A Review. Journal of Agriculturaland Food Chemistry. https://doi.org/10.1021/jf00021a002

TÜİK, 2020. Turkish Statistical Institute. BİRUNI. Available from: https://biruni.tuik.gov.tr/medas/?kn=92\&locale $=$ tr [Accessed: 18 May 2020].

Ayala-Zavala JF, Wang SY, Wan, CY, González-Aguilar GA. 2004. Effect of storage temperatures on antioxidant capacity and aroma compounds in straw berry fruit. LWT - Food Science and Technology. https://doi.org/10.1016/ j.lwt.2004.03.002 